\title{
PENGEMBANGAN SISTEM ANALISA KEBERPIHAKAN MEDIA ONLINE BERDASARKAN TREND WAKTU MENGGUNAKAN NAIVE BAYES CLASSIFIER
}

\author{
Faisal Rahutomo $^{1}$, Annisa Taufika Firdausi ${ }^{2}$, Nur Rochmanshah ${ }^{3}$ \\ 1,2,3 Teknik Informatika, Teknologi Informasi, Politeknik Negeri Malang

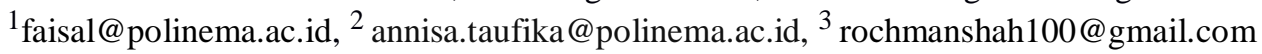

\begin{abstract}
Abstrak
Media online menjadi salah satu media yang paling penting dalam menyajikan informasi kepada para pembaca. Media online dapat menyajikan informasi kepada pembaca dengan cepat, gratis, dan praktis. Salah satu topik yang menjadi perhatian dari masyarakat Indonesia, khususnya di tahun 2019 adalah topik yang berkaitan dengan pemilihan Presiden dan Wakil Presiden. Banyak media online dalam penyajian berita di setiap hari, secara terangterangan maupun tidak, berpihak kepada salah satu Pasangan Presiden dan Wakil Presiden. Penyajian Media Online yang tidak netral ataupun tidak objektif tidak hanya merugikan bagi pihak Pasangan Presiden dan Wakil Presiden, tetapi juga mampu memberikan perspektif berbeda bagi pembaca atau masyarakat kepada pasangan Presiden dan Wakil Presiden terkait. Salah satu cara untuk menentukan atau mengetahui keberpihakan media kepada pasangan Presiden dan Wakil Presiden adalah dengan membuat sistem yang secara otomatis dapat mengklasifikasikan berita-berita yang ada pada suatu media di setiap hari atau waktu tertentu menjadi kategori yang telah ditentukan. Hasil pengklasifikasian kemudian diolah dan disajikan dalam bentuk grafik serta dihitung nilai keberpihakannya. Salah satu metode pengklasifikasian adalah dengan menggunakan metode Naive Bayes Classifier (NBC). NBC adalah klasifikasi statistik yang bisa memprediksi probabilitas sebuah kelas, dan kelebihan dari metode ini adalah tingkat akurasi yang tinggi juga waktu komputasi yang lebih cepat.
\end{abstract}

Kata Kunci : Analisa Keberpihakan Media Online, Pemilihan Presiden dan Wakil Presiden, Nä̈ve Bayes Classifier.

\section{Pendahuluan}

Media online adalah sebutan umum untuk sebuah bentuk media yang berbasis telekomunikasi dan multimedia (baca-komputer dan internet). Didalamnya terdapat portal, website (situs web), radio-online, TV-online, pers online, mail-online, dll, dengan karakteristik masing-masing sesuai dengan fasilitas yang memungkinkan user memanfaatkannya. Media online adalah media massa yang tersaji secara online di situs web (website) internet. Media online adalah media massa "generasi ketiga" setelah media cetak (printed media) koran, tabloid, majalah, buku, dan media elektronik (electronic media) radio, televisi, dan film atau video.

Di zaman modern, media online menjadi salah satu media yang paling penting dalam menyajikan informasi kepada para pembaca, Media online dapat menyajikan informasi kepada pembaca dengan cepat, gratis, dan praktis, bahkan untuk mengakses media online pun dapat melalui smartphone ataupun komputer yang terhubung dengan internet. Hal ini tentu memberikan manfaat kepada para pembaca dalam mendapatkan informasi terbaru di setiap harinya.
Dalam menyajikan berita, media online menyajikan berita-berita sesuai dengan beragam topik yang diminati oleh masyarakat, mulai dari yang berkaitan dengan Ekonomi, Olahraga, Bisnis, Teknologi, Kesehatan, Politik, dan sebagainya. Salah satu topik yang menjadi perhatian dari masyarakat Indonesia, khususnya di tahun 2019 adalah topik mengenai politik, terutama yang berkaitan dengan pemilihan Presiden dan Wakil Presiden. Hal tersebut juga dikarenakan bertepatan dengan diselenggarakannya pemilihan Presiden dan Wakil Presiden di tahun 2019.

Dalam hal yang berkaitan dengan Pemilihan Presiden dan Wakil Presiden 2019. Media online dapat berperan sebagai media yang menyampaikan informasi yang berkaitan dengan penyelenggaran Pemilihan Presiden dan Wakil Presiden 2019, ataupun yang berkaitan dengan hal-hal politik maupun non politik yang dilakukan oleh masingmasing pasangan Presiden dan Wakil Presiden. Pada hakikatnya, media itu memang harus objektif dalam melihat isu dan juga dalam pemberitaannya. Akan tetapi, pada kenyataannya justru banyak pemberitaan mengenai pasangan Presiden dan Wakil Presiden yang justru tidak netral atau tidak objektif, memihak 
kepada salah satu pasangan, bahkan menyudutkan pasangan yang lain. Banyak media online dalam penyajian berita di setiap hari, secara terang-terangan maupun tidak, berpihak kepada salah satu Pasangan Presiden dan Wakil Presiden. Penyajian Media Online yang tidak netral ataupun tidak objektif tidak hanya merugikan bagi pihak Pasangan Presiden dan Wakil Presiden, tetapi juga mampu memberikan perspektif berbeda bagi pembaca atau masyarakat kepada pasangan Presiden dan Wakil Presiden terkait. Baik itu berupa perspektif positif ataupun perspektif negatif.

Salah satu cara untuk menentukan atau mengetahui keberpihakan media kepada pasangan Presiden dan Wakil Presiden adalah dengan membuat sistem yang secara otomatis dapat mengklasifikasikan berita-berita yang ada pada suatu media di setiap hari atau waktu tertentu menjadi kategori yang telah ditentukan. Hasil pengklasifikasian berita, kemudian diolah dan disajikan dalam bentuk grafik serta dihitung nilai keberpihakannya untuk mengetahui keberpihakan media online kepada salah satu pasangan Presiden dan Wakil Presiden. Salah satu metode pengklasifikasian adalah dengan menggunakan metode Naive Bayes Classifier (NBC). NBC adalah klasifikasi statistik yang bisa memprediksi probabilitas sebuah kelas, dan kelebihan dari metode ini adalah tingkat akurasi yang tinggi juga waktu komputasi yang lebih cepat.

Berdasarkan pemaparan di atas, penelitian yang akan dilakukan adalah membangun sistem yang secara otomatis dapat mengklasifikasikan beritaberita yang ada pada media online menjadi kategori tertentu, serta sistem yang dapat menganalisa dan menentukan keberpihakan media online kepada pasangan Presiden dan Wakil Presiden berdasarkan waktu tertentu (trend waktu). Data berita yang akan digunakan untuk analisa dan menentukan nilai keberpihakan media online serta proses klasifikasi berita adalah data berita yang terdapat di portal-portal media online di Indonesia yang berkaitan dengan pemilihan presiden dan Wakil Presiden.

\section{Landasan Teori}

\subsection{Text Mining}

Pengklasifikasian artikel berita secara otomatis bisa dikategorikan sebagai text mining. Proses text mining dibagi menjadi 3 tahap utama, yaitu proses awal terhadap teks (text preprocessing), transformasi teks ke dalam bentuk antara (text transformation / feature generation), dan penemuan pola (pattern discovery). Manfaat dari text mining adalah untuk mencari pola dalam teks, yaitu proses penganalisisan teks guna menyarikan informasi yang bermanfaat untuk tujuan tertentu. Secara umum proses dalam text mining dilakukan dalam tiga tahapan yakni pemilihan data sebagai sumber informasi, kemudian dilakukan preprocessing dan analisis, dan yang terakhir adalah hasil dari proses yang menunjukkan interpretasi dari data yang diuji .

\subsection{Klasifikasi}

Klasifikasi teks merupakan sebuah teknik dalam text mining yang bertujuan untuk menempatkan teks pada kategori yang sesuai dengan karakteristiknya dari teks tersebut dengan menggunakan aturan-aturan tertentu. Dengan adanya klasifikasi teks, maka dapat memberikan pandangan secara konseptual mengenai cara pengelompokan data yang memiliki peranan penting terhadap dunia nyata. Tujuan dari pengkategorian teks adalah untuk mengklasifikasikan data ke dalam beberapa kategorikategori tertentu. Tiap dokumen dapat diklasifikasikan dalam beberapa kategori, atau tidak sama sekali. Dengan menggunakan machine learning, pembelajaran dapat dilakukan dengan aturan klasifikasi yang sudah ditentukan dan adanya data latih sebagai acuan pembelajaran sehingga dapat melakukan proses pengklasifikasian secara otomatis nantinya.

\subsection{Text Preprocessing}

Sebelum melakukan analisi teks, preprocessing harusnya dilakukan terlebih dahulu untuk mengeliminasi kata-kata yang tidak diperlukan. Hal ini bertujuan agar maksud dari kalimat lebih jelas lagi. Tahapan ini bertujuan untuk mempersiapkan teks menjadi data yang akan mengalami pengolahan pada tahapan berikutnya. Tindakan yang dilakukan meliputi tindakan kompleks dan tindakan sederhana. Contoh tindakan yang bersifat kompleks pada tahap ini adalah part-of-speech (pos) tagging, membangkitkan parse tree. Contoh tindakan yang bersifat sederhana adalah proses parsing sederhana terhadap teks, yaitu memecah suatu kalimat menjadi sekumpulan kata. Selain itu pada tahapan ini biasanya juga dilakukan case folding, yaitu pengubahan karakter huruf menjadi huruf kecil. Tahapan text preprocessing bertujuan untuk mempersiapkan text menjadi data yang akan mengalami pengolahan pada tahapan berikutnya. Terdapat tiga langkah dalam tahapan ini adalah Case Folding, Tokenizing, Filtering, Stemming. Case Folding bertujuan untuk mengubah seluruh huruf dari ' $a$ ' sampai dengan ' $z$ ' dalam dokumen menjadi huruf kecil. Tidak semua dokumen konsisten dengan penggunaan huruf kapital. Maka dari itu case folding mengkonversi keseluruhan teks dalam dokmen menjadi huruf kecil. Tokenizing, merupakan tahapan untuk memecah kalimat menjadi kata atau biasa disebut token. Selain itu, tahap ini juga bertujuan untuk membuang beberapa karakter yang dianggap sebagai tanda baca. Dalam proses tokenizing juga dilakukan pemisahan dokumen menjadi kata dasar, menghapus awalan, penyisipan, akhiran dan duplikasi. Filtering, tahap filtering adalah tahap mengambil kata-kata penting 
dari hasil tokenizing menggunakan algoritma algoritme stoplist (membuang kata yang tidak penting) dan wordlist (menyimpan kata yang penting). Tujuan umum dari proses ini adalah untuk mendapatkan representasi dasar dari dokumen yang diujikan. Stemming, stemming merupakan suatu proses yang mentransformasikan kata-kata yang terdapat dalam suatu dokumen ke kata-kata akarnya (root word) dengan menggunakan aturan-aturan tertentu. Sebagai contoh, kata bersama, kebersamaan, menyamai, akan diubah menjadi kata dasar "sama". Pencarian kata dasar pada setiap bahasa brbeda-beda, untuk bahasa Indonesia sendiri stemming menghilangkan imbuhan di awal, imbuhan berada ditengah, imbuhan berada diakhir, ataupum imbuhan di awal dan di akhir dari kata.

\subsection{Nä̈ve Bayes Classifier}

Naive Bayes didasarkan pada asumsi penyederhanaan bahwa nilai atribut secara kondisional saling bebas jika diberikan nilai output. Dengan kata lain, diberikan nilai output, probabilitas mengamati secara bersama adalah produk dari probabilitas individu.

Keuntungan penggunaan Nä̈ve Bayes adalah bahwa metode ini hanya membutuhkan jumlah data pelatihan (Training Data) yang kecil untuk menentukan estimasi paremeter yang diperlukan dalam proses pengklasifikasian. Nä̈ve Bayes sering bekerja jauh lebih baik dalam kebanyakan situasi dunia nyata yang kompleks dari pada yang diharapkan.

Nä̈ve Bayes adalah salah satu algoritma pembelajaran induktif yang paling efektif untuk machine learning dan data mining. Performa Nä̈ve Bayes yang kompetitif dalam proses klasifikasi walaupun menggunakan asumsi independen atribut tersebut dilanggar performa pengklasifikasian naïve bayes cukup tinggi, hal ini dibuktikan pada berbagai penelitian empiris .

Secara umum, proses klasifiksi dengan menggunakan metode Nä̈ve Bayes dapat digambarkan pada persamaan :

$$
P(C j \mid d)=\frac{P(d I C j) P(C j)}{P(d)}
$$

Keterangan :

$\mathrm{P}(\mathrm{Cj} \mid \mathrm{d})=$ probabilitas posterior bersyarat (conditional probability) suatu kejadian $\mathrm{H}$ terjadi jika diberikan evidence

$\mathrm{P}(\mathrm{Cj}) \quad=$ probabilitas awal (prior) kejadian $\mathrm{H}$ terjadi tanpa memandang evidence apapun.

$\mathrm{P}(\mathrm{d}) \quad=$ probabilitas awal (prior) evidence $\mathrm{X}$ terjadi tanpa memandang kejadian/ evidence yang lain.

$\mathrm{P}(\mathrm{d} \mid \mathrm{Cj})=$ probabilitas sebuah evidence $\mathrm{X}$ terjadi akan mempengaruhi hipotesis $\mathrm{H}$
Dengan pendekatan Nä̈ve Bayes yang mengasumsikan bahwa tiap-tiap kata didalam setiap kategori adalah tidak bergantung satu sama lain, maka perhitugannya dapat disederhanakan menjadi seperti berikut ini:

$$
P(C J \mid d)=\frac{N i c+1}{N c+V}
$$

Keterangan :

Nic = Jumlah dokumen latih dengan fitur atribut Wi dengan kategori $\mathrm{Cj}$

$\mathrm{Nc}=$ Jumlah dokumen dari kategori $\mathrm{Cj}$

$\mathrm{V}=$ Jumlah kategori

\section{Metode}

\subsection{Metodologi}

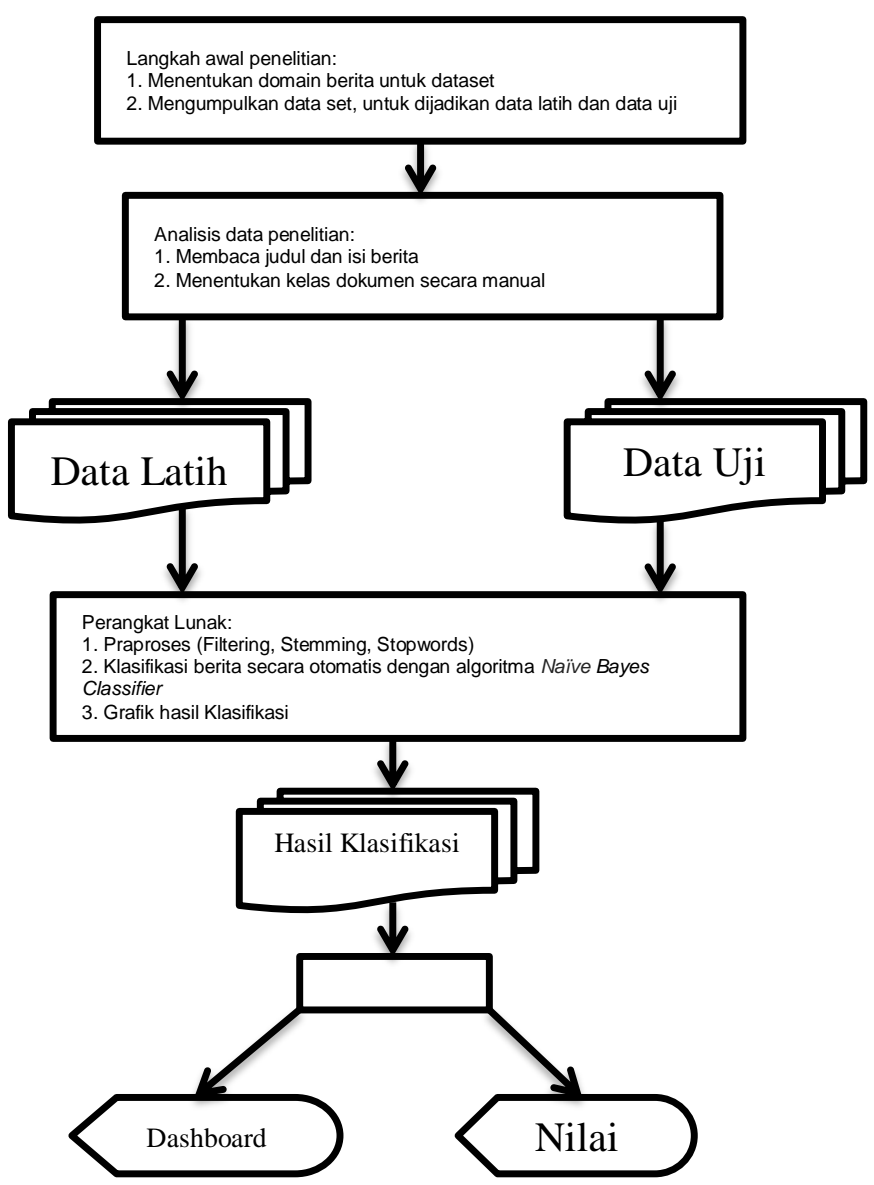

Gambar 1. Alur Metodologi Penelitian

Pada Gambar 1 menjelaskan langkah yang akan dilakukan dalam merancang sistem untuk keberpihakan media online menggunakan metode Nä̈ve Bayes Classifier dari tahapan penelitian adalah sebagi berikut, yaitu : Menentukan domain, Domain berita yang digunakan dalam penelitian ini adalah pilpres. berita yang mengandung kata kunci "pilpres" akan otomatis dikumpulkan. Pengumpulan Dataset, Data dalam penelitian ini bersumber dari website 
tempo.com dan medcom.com Pengambilan data menggunakan proses crawling. Preprocessing, Proses yang akan dilakukan pada tahap ini yaitu : Cleaning, yaitu proses membersihkan data berita dari kata-kata yang tidak mendeskripsikan sesuatu untuk mengurangi noise, selain penghapusan kata, dilakukan penghapusan tanda baca seperti koma (,) dan titik (.). Case folding, yaitu penyeragaman bentuk huruf, sehingga data hanya menjadi huruf latin dari a sampai z. Tokenizing, yaitu proses memecah sebuah kalimat menjadi kata. Klasifikasi, pada tahap ini akan dilakukan pengelompokkan tweet ke dalam kelas positif, negatif dan netral. Algoritma yang digunakan yaitu Nä̈ve Bayes Classifier. Setelah diklasifikasi maka akan diuji kualitas dari model yang dihasilkan dengan menghitung nilai akurasi. Dan data hasil klkasifikasi kemudian disajikan dalam bentuk grafik

\subsection{Studi Literatur}

Pada tahapan ini penelitian dilakukan dengan cara mempelajari berbagai literatur melalui pengumpulan dokumen-dokumen, referensireferensi, buku-buku, sumber dari internet, yang mendukung dan diperlukan untuk merancang sistem yang berkaitan dengan penulisan skripsi yang dilakukan.

\subsection{Dataset Berita dan Pengkategorian Berita}

Untuk mendapatkan data yang akan digunakan sebagai data uji adalah menggunakan proses crawling. Proses crawling data yang dibutuhkan dibatasi dengan waktu yang telah ditentukan. Data dengan jangka waktu yang telah ditentukan dari proses crawling kemudian akan menuju pada tahap text processing, yang bertujuan untuk memudahkan dalam proses pengklasifikasian data. Data berita pada masing-masing media, kemudian dikategorikan menjadi 5 kategori berita. Kategori berita dapat dilihat pada Tabel 1 .

Tabel 1. Kategori Berita

\begin{tabular}{|c|c|c|}
\hline No & Kategori & Keterangan \\
\hline 1 & Positif A & $\begin{array}{c}\text { Berita positif } \\
\text { untuk pasangan } \\
\text { A }\end{array}$ \\
\hline 2 & Positif B & $\begin{array}{c}\text { Berita positif } \\
\text { untuk pasangan } \\
\text { B }\end{array}$ \\
\hline 3 & Negatif A & $\begin{array}{c}\text { Berita negatif } \\
\text { untuk pasangan } \\
\text { A }\end{array}$ \\
\hline 4 & Negatif B & $\begin{array}{c}\text { Berita negatif } \\
\text { untuk pasangan } \\
\text { B }\end{array}$ \\
\hline 5 & Netral & $\begin{array}{c}\text { Berita positif } \\
\text { untuk pasangan } \\
\text { A dan B }\end{array}$ \\
\hline
\end{tabular}

Sebanyak 600 dokumen yang diperoleh dari proses crawling di website portal berita dibagi menjadi $70 \%$ sebagai dokumen latih dan $30 \%$ sebagai dokumen uji. Klasifikasi dengan Naive bayes classifier. Dalam metode Naive Bayes classifier dilakukan proses pengklasifikasian teks berdasarkan data latih yang sebelumnya telah ada didalam database sistem. Penelitian terkait Naive Bayes Classifiers melalui beberapa tahap. Evaluasi dilakukan dengan cara membandingkan antara hasil klasifikasi Naive Bayes Classifier dan hasil klasifikasi manual oleh petugas spkt polrestabes semarang serta dihitung akurasinya dengan menggunakan confussion matrix.

\section{Hasil dan Pembahasan 4.1 Pembagian Dataset}

Dari seluruh dataset berita yang sudah dikategorikan, diambil sebagian kemudian dibagi menjadi 4 sub dataset dengan rincian sesuai pada Tabel 2.

Tabel 2. Pembagian Dataset

\begin{tabular}{|c|c|c|c|c|c|}
\hline $\begin{array}{c}\text { Sub } \\
\text { Dataset }\end{array}$ & \multicolumn{5}{|c|}{ Jumlah Berita } \\
\cline { 2 - 6 } & $\begin{array}{c}\text { Positif } \\
\text { A }\end{array}$ & $\begin{array}{c}\text { Negatif } \\
\text { A }\end{array}$ & Netral & $\begin{array}{c}\text { Positif } \\
\text { B }\end{array}$ & $\begin{array}{c}\text { Negatif } \\
\text { B }\end{array}$ \\
\hline A & 6 & 6 & 6 & 6 & 6 \\
\hline B & 6 & 6 & 6 & 6 & 6 \\
\hline C & 6 & 6 & 6 & 6 & 6 \\
\hline D & 6 & 6 & 6 & 6 & 6 \\
\hline Total & 24 & 24 & 24 & 24 & 24 \\
\hline
\end{tabular}

Dalam proses pengujian, dataset berita yang telah terbagi ke dalam sub dataset, digunakan sebagai data testing sekaligus data training. Dalam cara pengujian, data testing sebagai data uji adalah data yang belum memliki kategori berita, sedangkan data training adalah data berita yang sudah memliki kategori.

Untuk mengkategorikan data testing yang belum memiliki kategori, akan diujikan ke data training dengan menggunakan metode Nä̈ve Bayes Classifer dan menentukan nilai Recall, Precision, dan Accuracy. Pengujian data training ke data testing, dengan rincian sesuai pada Tabel 3.

Tabel 3. Cara Pengujian

\begin{tabular}{|c|c|c|c|c|}
\hline $\begin{array}{c}\text { Pengujian } \\
\text { Ke - }\end{array}$ & $\begin{array}{c}\text { Data } \\
\text { Training } \\
\text { (Sub } \\
\text { Dataset) }\end{array}$ & $\begin{array}{c}\text { Jumlah } \\
\text { Data }\end{array}$ & $\begin{array}{c}\text { Data } \\
\text { Testing } \\
\text { (Sub } \\
\text { Dataset) }\end{array}$ & $\begin{array}{c}\text { Jumlah } \\
\text { Data }\end{array}$ \\
\hline 1 & A & 30 & B, C, D & 90 \\
\hline 2 & B & 30 & A, C, D & 90 \\
\hline 3 & C & 30 & A, B, D & 90 \\
\hline 4 & D & 30 & A, B, C & 90 \\
\hline
\end{tabular}




\subsection{Grafik Trend Waktu}

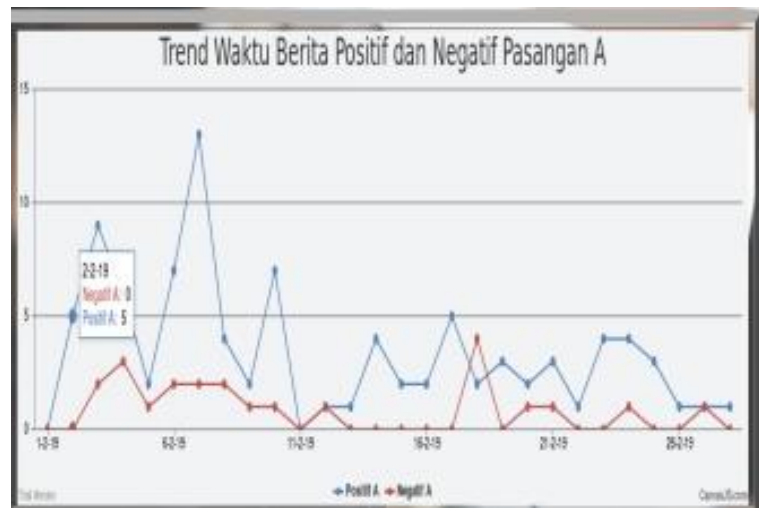

Gambar 2. Grafik Trend Waktu Berita Positif dan Negatif Pada Pasangan A di Media A

Pada Gambar 2 merupakan Grafik Trend Waktu jumlah berita positif dan negatif untuk pasangan $\mathrm{A}$ di media A.

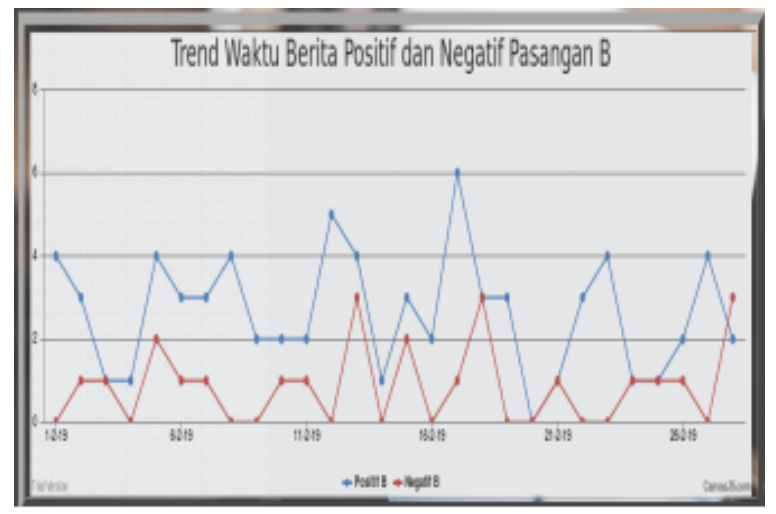

Gambar 3. Grafik Trend Waktu Berita Positif dan Negatif Pada Pasangan B di Media A

Pada Gambar 3 merupakan Grafik Trend Waktu jumlah berita positif dan negatif untuk pasangan B di Media A sesusai dengan dengan Tabel 1. Untuk jumlah berita positif dan negatif untuk masingmasing kategori pada masing-masing pasangan yang ada di media A sesuai dengan Tabel 4.

Tabel 4. Jumlah Berita Media A

\begin{tabular}{|c|c|c|c|}
\hline \multicolumn{4}{|c|}{ Jumlah Berita } \\
\hline Positif A & Negatif A & Positif B & Negatif B \\
\hline 95 Berita & 23 Berita & 74 Berita & 24 Berita \\
\hline
\end{tabular}

Untuk menghitung nilai keberpihakan pada pasangan A di Media A menggunakan rumus :

$$
\begin{aligned}
\text { Keberpihakan A } & =\sum_{\text {Negatif A }} \text { Berita Positif A }-\sum \text { Berita } \\
& =95 \text { Berita }-23 \text { Berita } \\
& =72 \text { Berita }
\end{aligned}
$$

Untuk menghitung nilai keberpihakan pada pasangan B di Media A menggunakan rumus :

$$
\begin{aligned}
\text { Keberpihakan B } & =\sum_{\text {Negatif B }} \text { Berita Positif B }-\sum \text { Berita } \\
& =74 \text { Berita }-24 \text { Berita } \\
& =50 \text { Berita }
\end{aligned}
$$

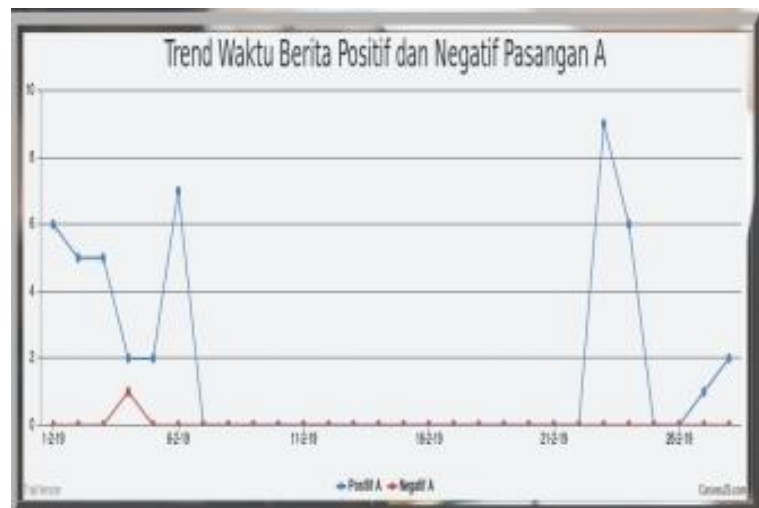

Gambar 4. Grafik Trend Waktu Berita Positif dan Negatif Pada Pasangan B di Media B

Pada Gambar 4 merupakan Grafik Trend Waktu jumlah berita positif dan negatif untuk pasangan A di media B.

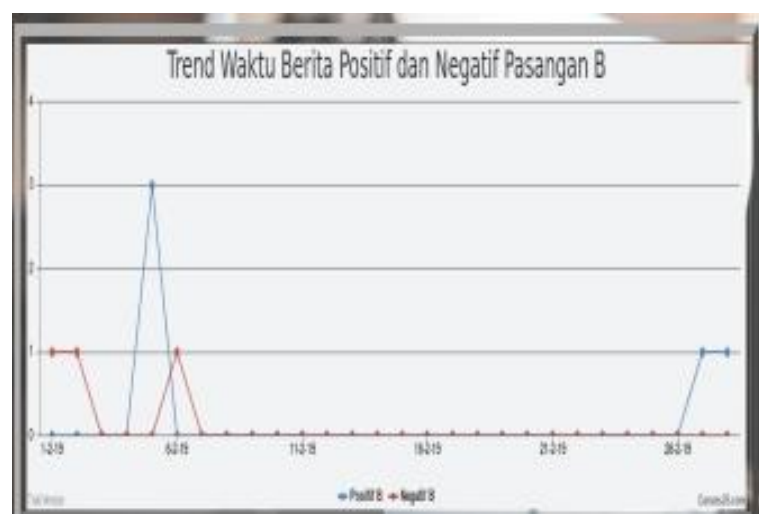

Gambar 5. Grafik Trend Waktu Berita Positif dan Negatif Pada Pasangan B di Media B

Pada Gambar 5 merupakan Grafik Trend Waktu jumlah berita positif dan negatif untuk pasangan B di media B.

Untuk masing-masing kategori pada masingmasing pasangan yang ada di media B sesuai dengan Tabel 5.

Tabel 5. Jumlah Berita Media B

\begin{tabular}{|c|c|c|c|}
\hline \multicolumn{4}{|c|}{ Jumlah Berita } \\
\hline Positif A & Negatif A & Positif B & Negatif B \\
\hline 65 Berita & 1 Berita & 12 Berita & 16 Berita \\
\hline
\end{tabular}

Untuk menghitung nilai keberpihakan pada pasangan A di Media A menggunakan rumus :

Keberpihakan A $=\sum$ Berita Positif A $-\sum$ Berita Negatif A 


$$
\begin{aligned}
& =65 \text { Berita }-1 \text { Berita } \\
& =64 \text { Berita }
\end{aligned}
$$

Untuk menghitung nilai keberpihakan pada pasangan B di Media A menggunakan rumus :

$$
\begin{aligned}
\text { Keberpihakan B } & =\sum_{\text {Negatif B }} \text { Berita Positif B }-\sum \text { Berita } \\
& =12 \text { Berita }-16 \text { Berita } \\
& =-4 \text { Berita }
\end{aligned}
$$

\subsection{Accuracy, Precision, dan Recall}

Accuracy merupakan tingkat ketepatan antara data atau informasi yang ditemukan oleh sistem dibandingkan dengan jumlah data sebenarrnya. Nilai Accuracy tertinggi adalah 1, yang berarti seluruh dokumen yang ditemukan adalah relevan.

$$
\text { Accuracy }=\frac{\sum \text { benar sistem }}{\sum \text { data sebenarnya }}
$$

Precision merupakan tingkat ketepatan antara informasi yang diminta oleh pengguna dengan jawaban yang diberikan oleh sistem. Nilai Precision tertinggi adalah 1, yang berarti seluruh dokumen yang ditemukan adalah relevan.

$$
\text { Precision }=\frac{\sum \text { ditemukan sistem }}{\sum \text { data sistem }}
$$

Recall merupakan tingkat keberhasilan sistem dalam menemukan kembali sebuah informasi. Nilai Recall tertinggi adalah 1, yang berarti seluruh dokumen dalam koleksi berhasil ditemukan.

$$
\text { Recall }=\frac{\sum \text { ditemukan sistem }}{\sum \text { data sebenarnya }}
$$

Hasil Pengujian Accuracy pada sistem dengan

\begin{tabular}{|c|c|c|c|c|c|}
\hline \multirow[b]{2}{*}{$\begin{array}{c}\text { Pengujian } \\
\text { Ke - }\end{array}$} & \multicolumn{5}{|c|}{ Hasil Pengujian Precision } \\
\hline & $\begin{array}{c}\text { Positif } \\
\text { A }\end{array}$ & $\begin{array}{c}\text { Positif } \\
\text { B }\end{array}$ & Netral & $\begin{array}{c}\text { Negati } \\
\text { A }\end{array}$ & Negatif $B$ \\
\hline 1 & $17 \%$ & $50 \%$ & $50 \%$ & $17 \%$ & $0 \%$ \\
\hline 2 & $17 \%$ & $50 \%$ & $67 \%$ & $50 \%$ & $67 \%$ \\
\hline 3 & $50 \%$ & $50 \%$ & $17 \%$ & $33 \%$ & $50 \%$ \\
\hline 4 & $33 \%$ & $33 \%$ & $33 \%$ & $50 \%$ & $17 \%$ \\
\hline
\end{tabular}
menggunakan metode Nä̈ve Bayes Classifier sesuai pada Tabel 6.

Tabel 6. Pengujian Accuracy

\begin{tabular}{|c|c|c|c|c|c|}
\hline $\begin{array}{c}\text { Pengujian } \\
\text { Ke - }\end{array}$ & $\begin{array}{c}\text { Data } \\
\text { Traing } \\
\text { (Sub } \\
\text { Dataset) }\end{array}$ & $\begin{array}{c}\text { Jumlah } \\
\text { Data }\end{array}$ & $\begin{array}{c}\text { Data } \\
\text { Testing } \\
\text { (Sub } \\
\text { Dataset) }\end{array}$ & $\begin{array}{c}\text { Jumlah } \\
\text { Data }\end{array}$ & $\begin{array}{c}\text { Hasil } \\
\text { Accuracy }\end{array}$ \\
\hline 1 & A & 30 & B, C, D & 90 & $27 \%$ \\
\hline 2 & B & 30 & A, C, D & 90 & $50 \%$ \\
\hline 3 & C & 30 & A, B, D & 90 & $40 \%$ \\
\hline 4 & D & 30 & A, B, C & 90 & $33 \%$ \\
\hline
\end{tabular}

Hasil Pengujian Precision pada sistem dengan

\begin{tabular}{|c|c|c|c|c|c|}
\hline \multirow[b]{2}{*}{$\begin{array}{c}\text { Pengujian } \\
\text { Ke - }\end{array}$} & \multicolumn{5}{|c|}{ Hasil Pengujian Recall } \\
\hline & $\begin{array}{c}\text { Positif } \\
\text { A }\end{array}$ & $\begin{array}{c}\text { Positif } \\
\text { B }\end{array}$ & Netral & $\begin{array}{c}\text { Negatif } \\
\text { A }\end{array}$ & \begin{tabular}{|c} 
Negatif \\
B
\end{tabular} \\
\hline 1 & $33 \%$ & $25 \%$ & $27 \%$ & $50 \%$ & $0 \%$ \\
\hline 2 & $17 \%$ & $75 \%$ & $44 \%$ & $75 \%$ & $57 \%$ \\
\hline 3 & $60 \%$ & $100 \%$ & $33 \%$ & $18 \%$ & $38 \%$ \\
\hline 4 & $33 \%$ & $50 \%$ & $25 \%$ & $38 \%$ & $25 \%$ \\
\hline
\end{tabular}
menggunakan metode Nä̈ve Bayes Classifier sesuai pada Tabel 7.
Tabel 7. Pengujian Precision

Hasil Pengujian Precision pada sistem dengan menggunakan metode Nä̈ve Bayes Classifier sesuai pada Tabel 8.

Tabel 8. Pengujian Recall

\section{Kesimpulan dan Saran}

Berdasarkan hasil penelitian dan pengujian tingkat akurasi yang telah dilakukan dapat ditarik kesimpulan bahwa dari hasil pengujian dengan Algoritma Naïve Bayes Classifier dapat digunakan untuk mengk(\$)ifikasikan kategori berita. Pada analisa keberpihakan media online berdasarkan trend waktu, dapat diambil kesimpulan bahwa Media A maupun media B berpihak kepada pasangan A dengan Nilai Keberpihakan 72 berita positif untuk pasangan A di Media A, dan 64 Berita Positif untuk pasangan A di Media B. Sedangkan untuk pasangan B, nilai keberpihakan di Media A adalah 50 berita positif dan di 5 dia B adalah -4 berita positif atau 4 berita negatif. Nilai perhitungan accuracy dari pengujian data testing dan data training dengan pembagian merata untuk setiap kategori di setiap sub dataset adalah pada besaran $27 \%, 50 \%, 40 \%$, dan $33 \%$.

Saran yang dapat diberikan dari hasil penelitian untuk pengembangan sistem ini ke depan bahwa penggunaan fitur dan tahap preprocessing yang berbeda untuk membandingkan tingkat akurasinya. Pengujian metode menggunakan dataset yang berbeda untuk membandingkan tingkat akurasinya. Optimasi proses pada sistem untuk meningkatkan performa dan memaksimalkan hasil pengujian sistem.

\section{Daftar Pustaka}

Ashadi Siregar. (2006): Etika Komunikasi, Pustaka Book Publisher.

Asep Syamsul M. Romli. (2012): Jurnalistik Online: Panduan Mengelola Media Online. Bandung. Nuansa Cendikia 
Even, Y. \& Zohar. (2002): Introduction to Text Mining, University of Illionis.

F Rahutomo, ZHR Adi, IF Rozi, PY Saputra (2018) : Implementasi Text Mining Pada Website/Blog Di Internet Untuk Menilai Kinerja Suatu Organisasi, INOVTEK Polbeng-Seri Informatika

F. Rahutomo, P. Y. Saputra, and M. A. Fidyawan. (2018): Implementasi Twitter Sentiment Analysis Untuk Review Film Menggunakan Algoritma Support Vector Machine, JIP, vol. 4, no. 2, p. 93, Feb.g. Thir.

Garcia, E. (2005): Document Indexing Tutorial for Information Retrieval Students and Search Engine Marketers. Available: http://www.miislita.com/information-retrievaltutorial/indexing.html

Hardiyanto, Erik., Rahutomo, Faisal., dan Puspitasari D., (2016) : Implementasi K-Nearest Neighbor (KNN) Pada Klasifikasi Artikel Wikipedia.

IYR Pratiwi, RA Asmara, F Rahutomo (2017) ; Study of hoax news detection using naïve bayes classifier in Indonesian language, 11th International Conference on Information \& Communication Technology and System (ICTS).

Kayser, V. (2016): Extending the knowlekaysdge base of foresight: The contribution of text mining. Elsevier, Issue Technological \& Sosial Change, pp. 208-215.

Nokbeh Zaeem, R. M.M.Y.Y. (2016): Modelling and analysist of identify threat behaviors through text mining of Identify theft stories. Elsevier, pp.50-63.

P. Y. Saputra, D. H. Subhi, and F. Z. A. Winatama. (2019): Implementasi Sentimen Analisis Komentar Channel Video Pelayanan Pemerintah Di Youtube Menggunakan Algoritma Nä̈ve Bayes, JIP, vol. 5, no. 4, pp. 209-213, Aug.

Rahayu. (2006): Potret Pofesionalisme dan Kualitas Pemberitaan Surat Kabar Indonesia. dalam Rahayu (ed.). Menyingkap Profesionalisme Kinerja Surat Kabar di Indonesia. Pusat Kajian Media dan Budaya Populer, Dewan Pers dan Departemen Komunikasi dan Informasi.

Sriram, B. (2010): Short Text clasification in twitter to improve information filtering. Preceeding of $33^{\text {rd }}$ international ACM SIGIR conference on Research and development in information retrieval, Volume SIGIR'10.

Thirafi, S.F.M., Rahutomo, F. (2018): Implementation of Nä̈ve Bayes Classifier Algorithm to Categorize Indonesian Song Lyrics Based on Age, International Conference on Sustainable Information Engineering And Technology (SIET), Malang, Indonesia, pp. 106-109.
Zhang, \& Gao, F. (2011): An Improvement to NB for Text Classification. Procedia Engineering, 15, 2160-2164. 
Volume 6, Edisi 1, November 2019

40 | H a 1 a $m$ a n 